\title{
PREDNOSTI IN OMEJITVE UPORABE KAZALCEV SONARAVNEGA RAZVOJA
}

\author{
Katja Vintar Mally \\ Oddelek za geografijo Filozofske fakultete Univerze v Ljubljani, Aškerčeva cesta 2, \\ SI - 1000 Ljubljana, Slovenija \\ e-mail: katja.vintar@ff.uni-lj.si
}

Izvirni znanstveni članek

COBISS 1.01

\section{Izvleček}

Prispevek prinaša kritično vrednotenje napredka na področju uporabe kazalcev sonaravnega razvoja v zadnjem desetletju. Predstavlja tudi nekatera metodološka in teoretična izhodišča njihove uporabe, različne modele kazalcev in merila, ki naj bi jim zadostili tako posamezni kazalci kot tudi njihovi nabori. Upoštevajoč dosedanjo prakso je glavni namen članka ovrednotiti prednosti in omejitve uporabe kazalcev sonaravnega razvoja ter osvetliti nekatera odprta vprašanja glede njihove prihodnje vloge pri merjenju napredka v smeri trajnosti.

Ključne besede: sonaravni razvoj, kazalci sonaravnega razvoja, metode, modeli, Slovenija

\section{ADVANTAGES AND LIMITATIONS OF SUSTAINABLE DEVELOPMENT INDICATORS}

\begin{abstract}
The article provides a critical evaluation of progress in the field of the use of sustainable development indicators over the last decade. It presents also some methodological and theoretical starting-points of their use, different indicator models and the criteria that should be met by individual indicators as well as by their sets. Considering the current practice, the main purpose of the paper is to evaluate the advantages and limitations of sustainable development indicators and to highlight some open questions about their future role in measuring progress towards sustainability.
\end{abstract}

Key words: sustainable development, sustainable development indicators, methods, models, Slovenia 


\section{UVOD}

Razumevanje odnosov med varstvom okolja in socialnoekonomskim razvojem se je v zadnjih dveh desetletjih nadgradilo v paradigmo trajnostnega razvoja (angl. sustainable development). Uveljavljanje nove razvojne paradigme kot ključnega dejavnika razvojnih politik na vseh prostorskih ravneh pa terja med drugim tudi stalno kvantitativno sledenje človekovim dejavnostim in preverjanje njihove ustreznosti. V tem smislu je pogosto govora o merjenju sonaravnosti, preko katerega ocenjujemo stopnjo oddaljevanja oziroma približevanja človekovih dejavnosti teoretično zasnovanim ciljem. Sonaravnost razumemo kot težnjo k trajnosti in njeno praktično udejanjanje, ki terja prilagajanje in uravnoteženje človekovih dejavnosti z nosilnimi zmogljivostmi okolja (Petek, 2001; Plut, 2002; Plut, 2005). Vendar tudi trajnost ni neko nespremenljivo stanje, pač pa jo je potrebno razumeti v smislu trajnega dinamičnega sistema, ki se lahko razvija, ne da bi se pri tem samouničeval. Posledično morajo biti številne sile, ki vplivajo na tak sistem, v ravnovesju (Hardi in drugi, 1997).

Od sredine devetdesetih let 20. stoletja sledimo pravemu razmahu različnih načinov merjenja sonaravnosti razvoja, ki pa se v večini primerov omejujejo na določanje raznolikih naborov kazalcev sonaravnega razvoja. Prispevek se zato loteva kritičnega pretresa smiselnosti oblikovanja in rabe tovrstnih kazalcev, njihovih prednosti in omejitev, tako s teoretičnega vidika kakor tudi na posameznih primerih iz prakse.

\section{TEORETIČNA IN METODOLOŠKA IZHODIŠČA}

Vrednotenje uporabe kazalcev sonaravnega razvoja v pričujočem prispevku je zasnovano na zahtevah paradigme trajnostnega razvoja, ki terja enakovredno in sočasno obravnavo gospodarskih, socialnih in okoljskih razsežnosti razvoja ter integracijo iz njih izhajajočih razvojnih ciljev. Zaradi močne medsebojne povezanosti in soodvisnosti socialnoekonomskih in okoljskih vidikov razvoja, jih je nujno obravnavati v enotnem ogrodju, kakršnega nudijo prav sistemi kazalcev sonaravnega razvoja. Oblikovanje slednjih je v svojem 40. poglavju zahtevala že Agenda 21 (1992), deset let pozneje pa tudi Implementacijski načrt (Plan..., 2002) $\mathrm{z}$ vrha $\mathrm{v}$ Johannesburgu. K spremljanju napredka so se $\mathrm{z}$ lastnimi nacionalnimi strategijami obvezale ne le posamezne države, ampak tudi skupine držav, kot na primer države članice Evropske unije s Strategijo trajnostnega razvoja (A Sustainable..., 2001). Razvoj kazalcev sonaravnega razvoja so neposredno ali posredno spodbudili tudi nekateri trendi na globalni ravni. Omeniti velja zlasti izboljšano razumevanje interakcij med ekosistemskimi storitvami in človekovo blaginjo, prepoznavanje vplivov ekonomske globalizacije na socialne in okoljske razmere, hiter napredek informacijskih in komunikacijskih tehnologij, vključno z geografskimi informacijskimi sistemi, kakor tudi povečano povpraševanje po raznolikih bazah podatkov, tudi za potrebe poročanja v okviru razvojnih strategij (npr. uresničevanje milenijskih razvojnih ciljev, mednarodnih sporazumov ipd.) (Pinter in drugi, 2005).

Ocenjevanje doseženega napredka v smeri trajnosti naj bi vključevalo pregled tako celotnega sistema kot tudi njegovih posameznih delov. Proučilo naj bi stanje blaginje ekonomskih, socialnih in okoljskih podsistemov, kot tudi smer in stopnjo sprememb tega 
stanja, njegovih sestavin ter njihovih medsebojnih odnosov (Assessing..., 1997). Slednje je v skladu s sistemsko teorijo, kjer se skuša vsak sistem razčleniti na podsisteme, nize in elemente ter ugotoviti, kako deluje skupina med seboj povezanih in soodvisnih elementov in kako njihovo spreminjanje vpliva na celoto, torej na sistem (Vrišer, 1992). S tem se približamo tudi enemu izmed osnovnih ciljev geografije, da na kompleksen način razloži "vrsto sistemov ali točneje podsistemov, ki sestavljajo pokrajino kot najbolj celovit in najbolj zapleten sistem na zemlji”" (Vrišer, 1992, 77).

Sisteme in odnose znotraj njih skušamo proučevati s pomočjo različnih modelov, ki predstavljajo sistematične in logične poenostavitve resničnosti. Modeli so nam v pomoč zlasti pri izbiranju in organiziranju posameznih tematik (vsebin) znotraj izbranega teoretičnega ogrodja, kar v naslednjem koraku predstavlja temelj opredeljevanja kazalcev za tako razvrščene vsebine. V devetdesetih letih 20. stoletja so se na področju (tudi geografskega) raziskovanja trajnosti oblikovali številni novi teoretični modeli oziroma ogrodja. Modeli si v sami osnovi pravzaprav ne nasprotujejo, ampak v glavnem predstavljajo zgolj različne poglede na odnose v proučevanem prostoru. V začetku so si najbolj široko veljavo pridobili modeli, zasnovani na odnosih pritiski - stanje - odzivi, ki so jih razvijali pri Organizaciji združenih narodov (Indicators..., 2001), Organizaciji za ekonomsko sodelovanje in razvoj (Birkmann, 1999; Radej, 1999), kakor tudi v Evropski uniji (Indicators..., 1997; Environmental..., 1999; Environmental..., 2002). Vzporedno so se razvili tudi modeli povezav med človeško in ekosistemsko blaginjo (Vester, 1991), tako imenovani tematski modeli in modeli različnih vrst kapitala (Hardi in drugi, 1997; Pinter in drugi, 2005). Le maloštevilni modeli so si izborili mednarodno veljavo, mnogi pa so obstajali že pred uveljavitvijo nove razvojne paradigme, kot na primer modeli različnih vrst kapitala in modeli pritiskov, stanj in odzivov. Slednje so različne organizacije razvile v več različicah (Slika 1), ki so se uveljavile zlasti na področju okoljskega poročanja, medtem ko se jih je za potrebe merjenja sonaravnosti razvoja pričelo v začetku 21. stoletja večinoma opuščati. Pinter s sodelavci za glavni razlog navaja dejstvo, da za določeno ugotovljeno stanje obstaja večje število pritiskov oziroma določen pritisk vpliva na spremembo večjega števila stanj. Oblikovanje takšnih modelov otežuje nepoznavanje in nedokazanost medsebojnih vzročnih povezav med temami, zaradi česar so nagnjeni k pretirani poenostavitvi povezav, pogosto pa je za posamezni kazalec tudi težko določiti, ali predstavlja pritisk ali stanje.

Za oblikovanje naborov kazalcev sonaravnega razvoja se dandanes najpogosteje uporablja tako imenovani tematski model (angl. theme model, issue- ali theme-based framework), ki je na najvišji hierarhični stopnji osnovan na proučevanju treh temeljnih razvojnih področij: ekonomskega, socialnega in okoljskega (Hardi in drugi, 1997; Indicators..., 2001). Nabor kazalcev sonaravnega razvoja se temu ustrezno sestoji iz ekonomskih, socialnih in okoljskih kazalcev, reprezentativnih za posamezne izbrane teme. Tematski model odlikujejo zlasti preglednost, razumljivost in enostavna organiziranost tematik, ki se neposredno nanaša na izvorne teoretične osnove nosilne paradigme. Znotraj ogrodja tematskega modela naj bi bil poudarek na enakovredni in sočasni obravnavi omenjenih treh temeljnih razsežnosti razvoja, pri čemer se vsakokrat presoja kazalce z vidika njihove vloge pri doseganju popolne integracije oziroma prepletanja zadanih ciljev na vseh prostorskih ravneh, kot načina doseganja trajnostnega razvoja (Slika 2). Zaradi pomanjkljivosti razpoložljivega teoretičnega 
Slika 1: Osnovno ogrodje modelov pritiski-stanje-odzivi

Figure 1: Pressure-state-response framework

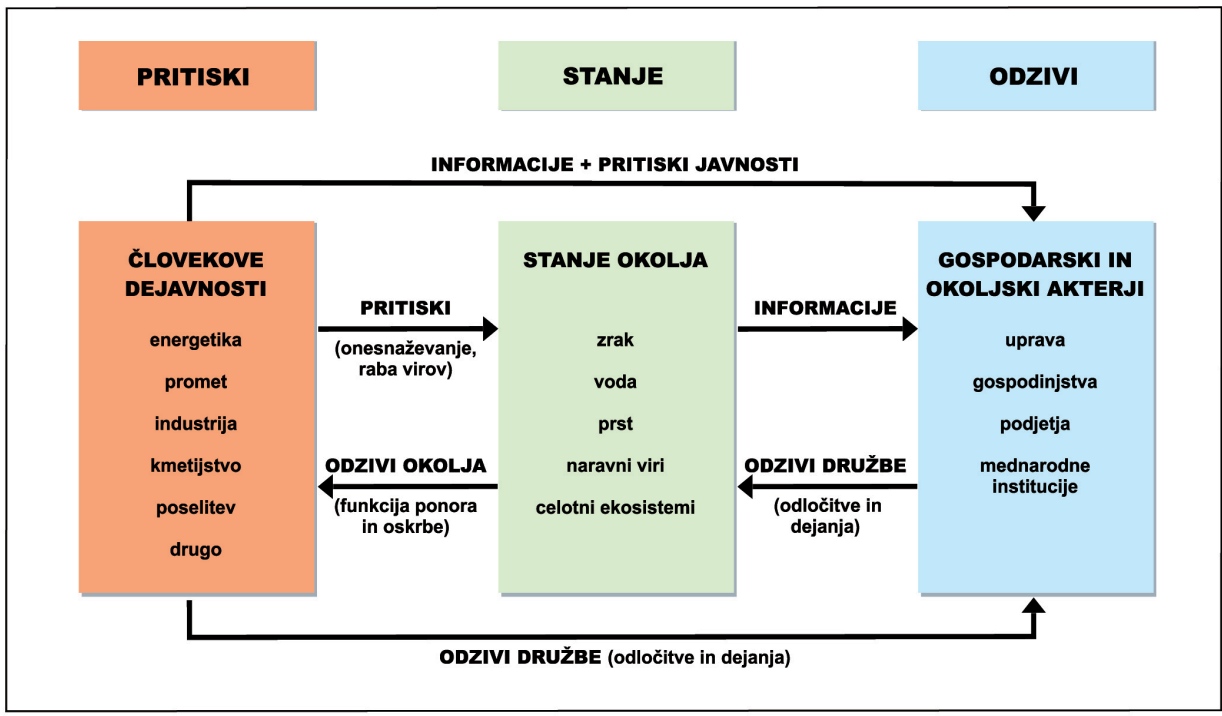

Vir: prirejeno po: Hardi in drugi, 1997; Birkmann, 1999.

Kartografija: Katja Vintar Mally, 200

Slika 2: Prepletanje razvojnih ciljev kot osnova tematskega modela

Figure 2: Integration of development goals as a basis for theme model

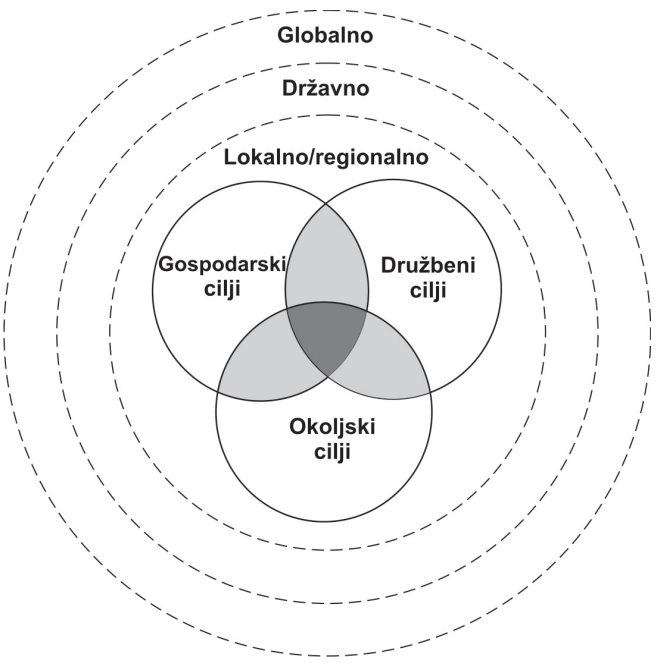

Delno prepletanje

Popolno prepletanje 
in metodološkega znanja je povsem razumljivo, da se uporabniki modela pogosto razlikujejo $\mathrm{v}$ predpostavkah, katere razvojne vidike naj bi posamezno temeljno razvojno področje (ekonomsko, okoljsko ali socialno) pokrivalo, kako so ti vidiki medsebojno povezani in na kakšen način ter s katerimi kazalci jih je primerno kvantitativno spremljati. Iz navedenih razlogov se razlikujejo tudi končni nabori kazalcev.

Izdelanost pogojev in načinov uporabe uvršča kazalce sonaravnega razvoja čedalje bolj ob bok ostalim metodam znanstvenega raziskovanja. Predstavlja postopke sistemskega in sistematičnega raziskovanja, ki so lahko uporabni na različnih prostorskih ravneh. Prispevek bo v nadaljevanju na podlagi analize svetovne in domače prakse preteklih let izluščil prav poglavitne napotke in razmisleke za prihodnja tovrstna prizadevanja.

\section{PREDNOSTI IN OMEJITVE KAZALCEV SONARAVNEGA RAZVOJA}

V vsakodnevnem življenju se z raznovrstnimi kazalci srečujemo praktično na vsakem koraku. Nudijo nam informacije, bistvene za razumevanje sveta, nam pomagajo pri sprejemanju odločitev in načrtovanju dejavnosti. Kazalci so med drugim tudi odsev naših vrednot, saj z njimi merimo le tisto, kar se nam v danem trenutku zdi pomembno. Sočasno pa kazalci zaradi zanimanja za namerjeno povratno vplivajo tudi na naš vrednostni sistem (Meadows, 1998). S kazalci sonaravnega razvoja se tako skušamo tudi praktično približati sicer zelo abstraktno opredeljeni vsebini trajnostne paradigme. Ob pravi inflaciji tovrstnih kazalcev v zadnjih letih se pogosto pozablja na določene osnovne zahteve njihovega oblikovanja in rabe, kakor tudi na nevarnosti pretiranega zaupanja vanje. Preden se posvetimo prednostim in omejitvam uporabe kazalcev sonaravnega razvoja bomo skušali podati še njihovo formalno oznako, izpostaviti merila za presojo primernosti kazalcev in določene pasti njihove uporabe.

Posamezni avtorji zelo različno opredeljujejo, kaj naj bi kazalec pravzaprav bil. Največkrat v povezavi s kazalci omenjajo poenostavljeno dojemanje sveta, kvantitativen prikaz različnih vsebin, nudenje smiselnih in koristnih informacij kot osnove za procese odločanja ter spremljanje udejanjanja politik, kakor tudi jasnost, enostavnost in povezanost s cilji oziroma referenčnimi vrednostmi (glej npr. Meadows, 1998; Born, 1999; Bossel, 1999; Indikatorji trajnostnega..., 1999; Koitka, Kreft, 2000; Gulič, Praper, 2000; Morse, 2004). Iz vsega naštetega niso razvidne zgolj osnovne poteze opredelitve kazalcev, ampak tudi njihove značilnosti in funkcije. Še najbolj enoznačno opredelitev nudi Radej (1999, 11), ki opredeljuje indikator ali kazalec kot sintezno izpovedno spremenljivko, pridobljeno iz dveh ali več podatkov. Pri tem je podatek lastnost (pojava), ki se meri ali opazuje. Pomen izračunanega kazalca presega sporočilnost, neposredno povezano z vrednostjo podatka, je sintezen in razvit za poseben, vnaprej določen namen. Že pred samim izborom in uporabo kazalcev se je nujno zavedati njihove velike pomanjkljivosti, ki izhaja iz dejstva, da so vsi kazalci le delni odsev subjektivno zaznane resničnosti. Svet namreč doživljamo preko določenih modelov, ki jih nosimo s seboj in jih tvorijo predpostavke in domneve o tem, kako ta svet deluje, kaj je pomembno in kaj naj bi merili. Na omenjene predpostavke vplivajo zlasti naša osebnost, kultura, jezik, izobrazba in izkušnje. Ker nihče nima popolnih informacij in ne razumemo vsega, kar se dogaja okoli 
nas, so naši mentalni modeli nujno nepopolni, hkrati pa tudi izjemno raznoliki (Meadows, 1998). Poleg tega na razumevanje ter vrednotenje pojavov in procesov vplivajo tudi različni vrednostni sistemi raziskovalcev. Različnemu dojemanju sveta se pridružuje še pomanjkljivo vedenje o delovanju sistemov in o vzročno-posledičnih zvezah med posameznimi sestavinami sistema. Vse to so glavni razlogi, zakaj je praktično nemogoče priti do vsesplošnega konsenza o naboru ustreznih kazalcev.

Izbor kazalcev za posamezna vsebinska polja znotraj izbranega modela je zagotovo najbolj zahteven in odgovoren raziskovalni korak. Odločanje o uvrstitvi posameznega kazalca v končni nabor mora biti povezano z obilico previdnosti in kritične presoje, pri kateri je smiselno upoštevati celo vrsto meril. Soočenje različnih napotil (Hardi in drugi, 1997; Meadows, 1998; Bossel, 1999; Franke, 1999; Indikatorji trajnostnega..., 1999; Seljak, 2000; Vintar, 2003; Morse, 2004; Final..., 2005) kot vsesplošno najbolj priporočljiva izpostavlja naslednja merila primernosti:

- relevantnost kazalca za politiko in odločanje, zaradi celovitega odražanja stanja, pojavov, procesov ali problemov;

- enostavnost kazalca $s$ čimbolj sledljivim načinom izračuna in jasno ter razumljivo vsebino, izraženo v predstavljivih enotah;

- nedvoumnost glede želene smeri gibanja kazalca (zelo priporočljiv je obstoj referenčne ali mejne vrednosti);

- orientiranje kazalca po mednarodnih smernicah in primerljivost izračunov na različnih prostorskih ravneh (lokalni, regionalni, državni in mednarodni);

- občutljivost kazalca na zaznavanje sprememb v času in prostoru ter po možnosti tudi med skupinami v družbi;

- enostavnost dostopa do podatkov ali merjenja pojava ter dostopnost kakovostnih podatkov za čim daljše časovne nize brez večjih časovnih zamikov;

- $\quad$ stroškovna sprejemljivost kazalca, ki ni povezana s prevelikimi stroški pridobivanja podatkov.

Poleg vseh naštetih meril je pomembno upoštevati tudi svarila pred pretiranim oziroma prešibkim agregiranjem podatkov, kakor tudi poziv k oblikovanju privlačnih in zanimivih kazalcev, ki so dostopni širši javnosti in jo spodbujajo k akciji. Seveda je opredelitev kazalcev, ki bi imeli vse želene lastnosti, možna le na najvišji analitično-teoretični ravni (Seljak, 2000), v praksi pa smo v določeni meri vedno prisiljeni spregledati tudi manjše pomanjkljivosti kazalcev. Ne glede na obseg prizadevanj po objektivnosti, je izbor kazalcev vedno vsaj deloma subjektiven, kajti že njihova izbira sama temelji na subjektivnem prepričanju posameznika ali skupine, da so pomembni za merjenje določene razsežnosti sonaravnosti. Na vseh stopnjah raziskovanja se je zato nujno zavedati, da idealni kazalci ne obstajajo in so uporabljeni kazalci le boljši ali slabši nadomestki tistih, ki naj bi povsem zajeli določene pojave, stanja in procese.

Nekateri avtorji opozarjajo še na dodatne pasti izbora in uporabe kazalcev sonaravnega razvoja (glej npr. Meadows, 1998; Indikatorji trajnostnega..., 1999), skaterimi se sčasoma sooči vsak raziskovalec. Pri iskanju ustreznega kazalca za določeno tematiko se lahko v pomanjkanju ustreznih podatkov zatečemo $\mathrm{k}$ uporabi razpoložljivih podatkov. Rezultat je proučevanje merljivega, namesto tistega, kar je dejansko pomembno. Nepoznavanje součinkovanja med 
posameznimi razvojnimi vidiki nas lahko zavede k uporabi napačnih modelov povezav med kazalcem in pojavom, ki naj bi ga kazalec dejansko pojasnjeval. Podobno zavajajoče je pretirano zaupanje v kazalce oziroma podatke, zlasti če jim verjamemo bolj kot pa predhodnim neposrednim izkušnjam. Obratno pa je prav tako strokovno povsem nesprejemljivo (zavestno) potvarjanje v obliki izpuščanja "neustreznih" podatkov, ki ne prinašajo želenih informacij, ali prikrojitve definicij oziroma statističnih podatkov. Pomanjkljivosti se pogosto skrijejo tudi s pretiranim agregiranjem kazalcev, ki načeloma zakrije vsebino vhodnih podatkov in oteži razumevanje samega sinteznega kazalca. Ne glede na korektnost postopkov vedno velja zadržek, da so kazalci nepopolni in nikoli ne zajamejo sistema v celoti. Posledično je še toliko bolj pomembno, da uporabo vsakega kazalca spremlja tudi natančna opredelitev postopkov izračuna, kritični pretres vsebinskega dometa kazalca, prednosti in pomanjkljivosti njegove uporabe, kakor tudi kakovosti razpoložljivih podatkov.

Pri oblikovanju sistema kazalcev ni izjemno pomembna samo kakovost vsakega posameznega vključenega kazalca, ampak tudi njihovo uravnoteženo povezovanje v sistem. Kazalci sonaravnega razvoja namreč večinoma sploh niso novi kazalci, ki bi bili razviti posebej v ta namen, ampak so po svoji naravi primarno okoljski, ekonomski ali pa socialni kazalci. Sami po sebi tako niso pokazatelji sonaravnosti, a ko jih vse skupaj umestimo v koncept sonaravnega razvoja, dobijo v njem svojo pojasnjevalno vrednost. Šele sistem, ki ga tako tvorijo, nam nudi bolj celovito predstavo o nekem prostoru. Zato se ne smemo zadovoljiti samo z izračunom posameznih kazalcev, ampak je potrebno iskati tudi vzroke za stanje pojavov, ki nam jih ti kazalci predstavljajo, pojasniti njihovo učinkovanje na druge pojave v sedanjosti in opozoriti na njihove možne posledice v prihodnosti.

Najpomembnejši omejujoč faktor pri oblikovanju sistema kazalcev je razpoložljivost podatkov. Tako obstaja nevarnost, da v odvisnosti od velike količine podatkov, ki jih imamo na razpolago za posamezne teme, le-te bolj izpostavimo in zanje izračunavamo večje število kazalcev kot pa za tiste teme, za katere so na voljo skromnejši podatki (Frings, 1999, 53). Takšen sistem kazalcev bo neuravnotežen in lahko s svojimi izsledki obrača pozornost od pravih problemov. Iz tega razloga je potrebno pri vsakem naboru kazalcev posebej izpostaviti tudi vsebinska področja s pomanjkljivimi podatki in opozoriti na ugotovljeni primanjkljaj, razmere pa poskušati ovrednotiti vsaj opisno. Nenazadnje strateških odločitev ne smejo voditi le količinski indikatorji, saj mnogih pomembnih področij človekovega življenja ni mogoče kvantitativno opredeliti (npr. svoboda, ljubezen, harmonija, lepota...).

Med prednosti kazalcev sonaravnega razvoja ne gre prištevati zgolj že omenjenega poenostavljenega in zgoščenega podajanja bistvenih informacij, ampak zlasti njihovo širšo uporabnost za spremljanje napredka pri doseganju sonaravnosti na obravnavanem območju. $\mathrm{Z}$ vidika procesa odločanja in načrtovanja prihodnjega razvoja nam lahko kazalci služijo kot (Hardi in drugi, 1997, str. 7):

- $\quad$ orodje za razlaganje oziroma pojasnjevanje, ki prevaja koncept sonaravnosti/trajnosti v praktične okvire, kar je v pomoč zlasti pri opredeljevanju konkretnih razvojnih ciljev;

- $\quad$ orodje za načrtovanje, ki usmerja politične odločitve in tvori podlago za načrtovanje prihodnjih dejavnosti;

- $\quad$ orodje za ocenjevanje učinkovitosti, ki tvori empirično in kvantitativno bazo za vrednotenje učinkovitosti prizadevanj za doseganje zastavljenih ciljev. 
Na področju sonaravnega razvoja je glavni pomen in naloga kazalcev, da nam predstavijo stanje in trende v času in prostoru ter nam služijo kot izhodiščna točka za nadaljnje ukrepanje. Velika prednost poenotenih naborov kazalcev oziroma metodološko usklajenih kazalcev je tudi možnost primerjav med regijami in državami. S kazalci lahko spremljamo in nadziramo napredek ter učinkovitost politik pri doseganju zahtev sonaravnosti, ponujajo pa nam tudi priložnost iskanja novih korelacij med pojavi, ki jih teoretično še nismo uspeli razjasniti. Zelo pomembno je dejstvo, da se z njihovo pomočjo tudi širši javnosti nudi vpogled $\mathrm{v}$ stanje okolja, družbe in gospodarstva ter jo seznanja z doseganjem oziroma približevanjem ali oddaljevanjem od zastavljenih ciljev, kar ima za posledico tudi bolj konkretno razumevanje koncepta sonaravnega razvoja (Hönerbach, 1999, 14 in 15). Potreba po kontinuiranem spremljanju in izračunavanju kazalcev se zato zdi samoumevna.

Pri uporabi kazalcev sonaravnega razvoja naletimo na številne omejitve. Nekatere smo predhodno že omenili pri opisovanju pasti neprimernega oblikovanja in rabe kazalcev. V nadaljevanju bi se v skladu s klasifikacijo Pinterja in sodelavcev (2005) omejili zlasti na institucionalne, tehnične in metodološke omejitve kazalcev sonaravnega razvoja. Z institucionalnega vidika je poglavitno vprašanje vključenosti kazalcev v procese odločanja. Kljub vsesplošni načelni podpori trajnostni paradigmi ostaja proučevanje sonaravnosti še vedno pretežno $\mathrm{v}$ domeni okoljskih organizacij $\mathrm{z}$ relativno šibkim vplivom na glavni tok dnevne politike. Kazalci sonaravnega razvoja predstavljajo $\mathrm{v}$ glavnem zgolj dopolnilno informacijo ob že obstoječih sistemih poročanja, zaradi česar po prvotnem razcvetu tudi niso doživeli pričakovanega izboljšanja, ki bi zahtevalo tudi večji angažma vladnih institucij. S tem povezane so tehnične omejitve, ki se nanašajo zlasti na kakovost in razpoložljivost podatkov. Problematično ni le pomanjkanje podatkov, ampak tudi razhajanje definicij in načinov zajema podatkov, pri čemer podatki za različne prostorske ravni pogosto sploh niso primerljivi oziroma zaradi spreminjanja metodologij ni mogoče pridobiti veljavne časovne vrste podatkov. Zaradi dolgotrajnosti usklajevanja tehničnih podrobnosti in pridobivanja ustreznih podatkov je rezultate mogoče pričakovati šele po več letih. Slednje je tesno povezano tudi z metodološkimi omejitvami kazalcev sonaravnega razvoja, ki se nanašajo zlasti na odsotnost konsenza glede enotnega nabora kazalcev, torej odločitve, kaj pravzaprav meriti in na kakšen način.

Opredelitvi in izračunu kazalcev sonaravnega razvoja mora slediti tudi faza sinteznega vrednotenja pridobljenih rezultatov, pri kateri trčimo ob dodatno oviro. Za presojanje, v kolikšni meri se vrednosti posameznega kazalca približujejo ali oddaljujejo od želenega, bi namreč kot izhodišče nujno potrebovali določeno mejno ali referenčno vrednost. Medtem ko za nekatere vnose škodljivih snovi v okolje že obstajajo zakonsko določene mejne in kritične vrednosti, pri večini drugih kazalcev takšen konsenz ni bil dosežen. Tako ne moremo govoriti, kje je na primer meja med "sonaravnim" in "nesonaravnim" pri rabi posameznih naravnih virov na prebivalca, ustvarjenem bruto domačem proizvodu ali pričakovani dolžini življenja. Odsotnost mejnih vrednosti po mnenju mnogih predstavlja glavno oviro operacionalizaciji sonaravnega razvoja. Vzrok tiči na eni strani v pomanjkljivem poznavanju povezav tako $\mathrm{v}$ naravi sami kot tudi medsebojnih povezav gospodarstva in okolja ter posledic gospodarskih dejavnosti, na drugi strani pa v pomanjkanju politične pripravljenosti, da se takšne mejne vrednosti sprejme in uzakoni (Kistenmacher, Mangels, 2000). Na trenutni stopnji poznavanja problematike smo se običajno prisiljeni zadovoljitizopisnimi opredelitvamiv smislu negativnih 
in pozitivnih gibanj vrednosti kazalcev. Ker imamo v naborih kazalcev običajno opravka z večjim številom gospodarskih, socialnih in okoljskih kazalcev, jih želimo v naslednjem koraku preoblikovati na način, ki bo omogočal vsaj delno agregiranje in bolj celovito primerjavo proučevanih prostorskih enot med seboj. Zaradi neobstoja referenčnih vrednosti zahteva tudi ta korak iskanje nadomestnih rešitev. Večina do sedaj uporabljenih metod standardizacije in agregiranja kazalcev sonaravnega razvoja ostaja na bolj eksperimentalni ravni in zaenkrat še ni pridobila splošne veljave. Iskanje skupnega imenovalca raznolikim okoljskim, socialnim in ekonomskim kazalcem ostaja eden poglavitnih izzivov prihodnjega raziskovanja, saj se v nasprotnem primeru uporabniki utapljajo v velikih količinah podatkov. Nabori kazalcev bi v idealnem primeru morali nuditi tako primerjavo podatkov znotraj posameznega kazalca, kakor tudi primerjave posameznih skupin (ekonomskih, socialnih in okoljskih) kazalcev oziroma sinteznega kazalca sonaravnega razvoja, sestavljenega iz vseh vključenih kazalcev.

\section{KAZALCI SONARAVNEGA RAZVOJA MED TEORIJO IN PRAKSO}

Pregled domače in tuje prakse na področju opredeljevanja in izračunavanja kazalcev sonaravnega razvoja potrjuje tezo o razcvetu tovrstnih prizadevanj $\mathrm{v}$ zadnjem desetletju. Junija 2006 je mednarodni inštitut za trajnostni razvoj (International Institute for Sustainable Development) v svoji bazi, ki je verjetno najbolj popolna tovrstna svetovna zbirka, beležil kar 684 vnosov različnih iniciativ oblikovanja kazalcev sonaravnosti (Compendium..., 2006). Mednje se uvrščajo iniciative nekaterih mednarodnih organizacij, ki so na podlagi svojih modelov sonaravnega razvoja oblikovale lastne sisteme in izračune kazalcev. Njihovemu zgledu (zlasti zgledu kazalcev Organizacije združenih narodov) so sledile tudi nekatere države, druge pa so samoiniciativno izoblikovale svoje nabore kazalcev (npr. Kanada, Nizozemska, Velika Britanija). Poleg tega lahko zasledimo nekaj odmevnejših poskusov formiranja sistemov kazalcev sonaravnega razvoja tudi na regionalnih ravneh (npr. BadenWürttemberg) in celo vrsto takšnih iniciativ na lokalnih ravneh (npr. Seattle, Winnipeg, Santa Monica v ZDA, Bremen, Hamburg...). Celoten spekter tovrstnih dejavnosti je zelo obsežen in nepregleden, saj ne vključuje le mednarodnih organizacij in različnih ravni državnih uprav, ampak tudi okoljevarstvene in druge nevladne organizacije ter celo podjetja, ki želijo preko različnih kazalcev spremljati sprejemljivost svojega poslovanja. V nadaljevanju bomo na izbranih primerih, ki neposredno zadevajo tudi Slovenijo, prikazali še praktične razsežnosti predhodno navedenih razmišljanj o prednostih in omejitvah kazalcev sonaravnega razvoja.

Pionirsko delo na področju oblikovanja kazalcev sonaravnega razvoja je zagotovo opravljala ustrezna komisija Združenih narodov (United Nations Commission for Sustainable Development), ki je leta 1996 predstavila seznam skupno 132 kazalcev za spremljanje napredka na ravni držav sveta. Vsak kazalec je natančno opredelila z definicijo, načinom izračuna in razlago njegovega pomena $\mathrm{z}$ vidika zagotavljanja sonaravnega razvoja. Izbor posameznih kazalcev je tematsko neposredno sledil poglavjem Agende 21 in jih razvrščal $\mathrm{v}$ kategorije ekonomskih, socialnih, okoljskih in institucionalnih kazalcev. Znotraj teh štirih osnovnih kategorij so še dodatno razločevali kazalce pritiskov oziroma gonilnih sil, 
kazalce stanja in kazalce odzivov (Indicators..., 1997). Do leta 1999 so nato celotni nabor kazalcev testirali v 22 izbranih državah na vseh celinah (v Evropi so jih preizkušale Avstrija, Belgija, Češka, Finska, Francija, Nemčija in Velika Britanija). Preizkušanje kazalcev v praksi je njihovo število praktično prepolovilo, saj se je za mnoge izkazalo, da jih je zaradi pomanjkanja podatkov težko pridobiti, da niso metodološko dorečeni ali pa so v posameznih državah nerelevantni (Indicators..., 2001; Pinter in drugi, 2005). Do podobnih ugotovitev so prišli tudi pri Eurostatu, ko so po isti metodologiji izračunavali kazalce za države članice EU in jih uspeli na ta način pridobiti le 46 (Indicators..., 1997). V naslednjem koraku je bil zato nabor kazalcev skrčen na 58 kazalcev, opuščena je bila uporaba klasifikacije kazalcev na gonilne sile, pritiske in odzive, omiljena pa je bila tudi prej stroga vsebinska naslonitev na Agendo $21 \mathrm{v}$ korist spremljanja prednostnih ciljev (Pinter in drugi, 2005). Omenjena iniciativa je dokazala, da je oblikovanje splošno veljavnega nabora kazalcev za vse države sveta zelo težavna naloga, še posebej zaradi raznolikosti razvojnih problemov, s katerimi se soočajo gospodarsko razvite države na eni in države v razvoju na drugi strani. Kljub napredku pri opredeljevanju posameznih kazalcev pa ostaja praktično brez rezultatov trud komisije, da bi nadgradila uporabo individualnih kazalcev še z agregiranjem. Večina sodobnega proučevanja uravnoteženosti ekonomskega, socialnega in okoljskega razvoja na globalni ravni tako še vedno ostaja na stopnji analiziranja posameznih pokazateljev, njihovih preteklih trendov, iskanja povezav med različnimi spremenljivkami in ocenjevanja dolgoročne sprejemljivosti posameznih razvojnih vidikov.

Slovenija pa ni dolžna poročati samo Organizaciji združenih narodov, ampak jo kot članico neposredno zadevajo tudi ambicije Evropske unije, da postane vodilna svetovna sila pri doseganju ciljev trajnosti. V skladu s tem je trajnostni razvoj kot eden izmed vodilnih ciljev zapisan tudi v Pogodbi o Evropski uniji, podkrepljen z ustrezno strategijo - "Trajnostni razvoj Evrope za boljši svet”, sprejeto na Evropskem svetu v Göteborgu, junija 2001 (A Sustainable..., 2001). Septembra 2001 je bila ustanovljena tudi posebna delovna skupina za razvoj kazalcev sonaravnega razvoja, ki je do leta 2005 oblikovala nabor 155 kazalcev. Kazalci so razporejeni v hierarhični tematski model s skupno desetimi glavnimi temami, ki jih predstavlja 12 nosilnih kazalcev prve stopnje, 45 kazalcev druge stopnje in 98 kazalcev tretje stopnje (Final..., 2005; Measuring..., 2005). Nosilne teme sledijo v strategiji zastavljenim ciljem in razkrivajo znatno pomanjkanje ustreznih podatkov oziroma razhajanje med razpoložljivimi ("best-available") in potrebnimi ("best-needed”) kazalci. Izračunavanje izbranih kazalcev opozarja na nujnost izboljšanja obstoječih podatkov. Le $69 \%$ kazalcev ima za objavo primerne podatke, medtem ko za nobeno temo ni na voljo vseh podatkov (Slika 3). S podatki najslabše zastopani in metodološko najmanj razjasnjeni so kazalci za spremljanje kakovosti in varnosti hrane, ravnanja s kemikalijami, zdravstvenih tveganj zaradi stanja okolja, odgovornosti podjetij, biotske raznovrstnosti, morskih ekosistemov, rabe tal, prometa, kakovosti upravljanja in rabe naravnih virov. Največji primanjkljaj podatkov je na socialnem in okoljskem področju, vendar v prihodnosti ne bo zadostovalo le zbiranje novih podatkov, ampak bo potreben tudi drugačen pristop k že obstoječim. Prepletanje ekonomskih, socialnih in okoljskih razsežnosti razvoja namreč zahteva nove načine soočanja statističnih spremenljivk, saj kazalci pogosto ne pripadajo le eni skupini, ampak so značilni za dve ali celo vse tri (npr. izdatki za varstvo okolja, revščina ipd.). V okviru omenjenih vsebin bodo morale vse države članice v prihodnjih letih 
vložiti še veliko sredstev in naporov, da bo tudi dejansko omogočeno spremljanje napredka na vseh razvojnih poljih.

Slika 3: Kakovost podatkov nabora kazalcev sonaravnega razvoja EU po temah

Figure 3: Data quality of the EU - sustainable development indicators set according to themes

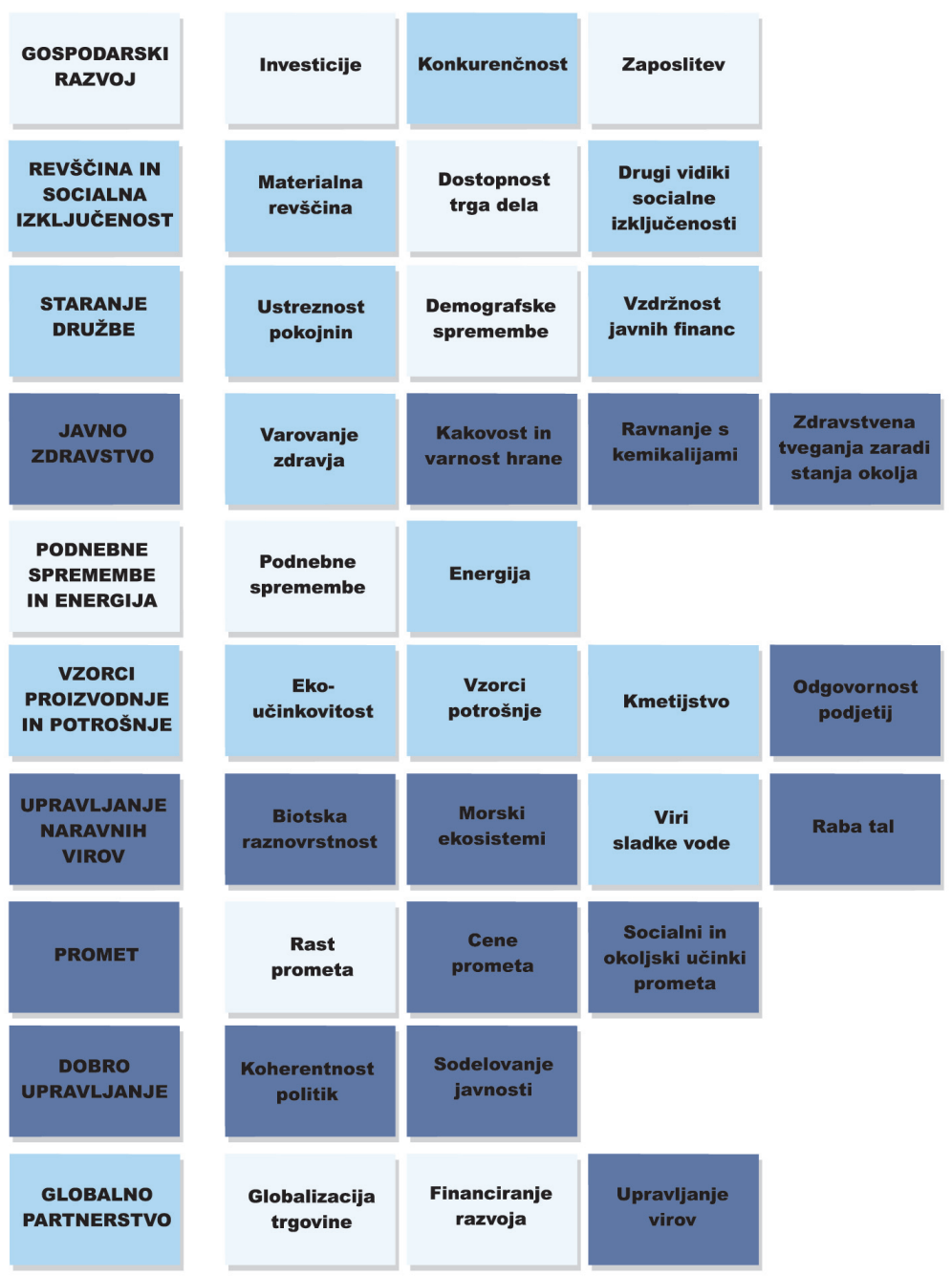


Iz obeh predhodno predstavljenih primerov mednarodnih naborov kazalcev je razvidno pomanjkanje ustreznih podatkov oziroma kazalcev, ki je še bolj izrazito, ko želimo takšne nabore uporabiti na hierarhično nižjih prostorskih ravneh. V preteklem desetletju je bilo tudi v Sloveniji opravljenih nekaj raziskav s področja kazalcev sonaravnega razvoja. V ospredju je bilo zlasti izračunavanje kazalcev za državno raven, pri čemer je metodološko izstopal predvsem Seljakov (2001) kazalec uravnoteženega razvoja, pridobljen iz skupno 154 kazalcev. Njegovi izsledki so bili uporabljeni tudi za poročilo Slovenije na Svetovnem vrhu o trajnostnem razvoju v Johannesburgu (2002) in v nekaterih vidnejših publikacijah (npr. Poročilo o razvoju, 2002). Več iniciativ je bilo zaslediti na lokalni ravni (npr. za mediteransko regijo v okviru projekta Blue Plan, za mestno občino Ljubljana, v okviru poskusov izdelave lokalnih agend in podobno), medtem ko smo vrzel na regionalni ravni skušali zapolniti z naborom 32 kazalcev, ki v okviru tematskega modela nudi celovit pregled za slovenske statistične regije (Vintar, 2003). Tudi na tem primeru opredeljevanja kazalcev so se potrdile tuje izkušnje, da je za celovito pokrivanje socialnih in okoljskih tematik potrebno znatno večje število kazalcev kot za ekonomsko področje, kjer so bili v daljši zgodovini izračunavanja razviti bistveno bolj sintezni kazalci (npr. sistem nacionalnih računov). Iz tega izhaja neuravnoteženost $\mathrm{v}$ skupnem številu izbranih kazalcev, saj je potrebno sorazmerno malo število ekonomskih kazalcev (6), večje število socialnih kazalcev (12), medtem ko so številčno najbolj zastopani okoljski kazalci (14) (Preglednica 1). Nabor kazalcev je na eni strani odraz trenutnega poznavanja in vrednotenja razvojnih vprašanj ter poznavanja delovanja sistemov in vzročno-posledičnih zvez znotraj njih, na drugi strani pa nedvomno tudi razpoložljivosti podatkov, za obstoj katerih je predpogoj, da se zdijo družbi in posameznikom pomembni in uporabni. Vsak sistem kazalcev mora biti zato odprt za morebitne dopolnitve in izboljšave, ki bodo v bodoče izvirale bodisi iz novo pridobljenih znanj, bodisi iz sprememb vrednostnega sistema. Prav tako nas omejena razpoložljivost podatkov na regionalni ravni sili v uporabo nadomestnih in reprezentativnih kazalcev, zlasti še na okoljskem področju. Za celo vrsto kazalcev namreč obstajajo podatki in preračuni le za državno raven, ne pa tudi za nižje hierarhične ravni. Za takšne tematike je zato potrebno iskati alternativne rešitve, ki pa posledično največkrat niso mednarodno primerljive. Kljub temu ostaja vrsta tem nepokritih oziroma bi zahtevale iskanje načinov izračunov bolj sinteznih kazalcev (npr. skupno energetsko obremenjevanje kmetijstva, skupno onesnaževanje ozračja, skupno onesnaževanje in kakovost voda, nastajanje in ravnanje z odpadki in podobno).

Znamenom bolj celovitega vrednotenja razvojnih gibanj slovenskih regij na ekonomskem, socialnem in okoljskem področju so bili navedeni kazalci tudi agregirani. Uporabljena so bila enotna merila in ocene za vse vključene kazalce. Zaradi neobstoja mejnih oziroma referenčnih vrednosti so bile ocene oblikovane $\mathrm{z}$ uporabo standardnega odklona kot enotnega kriterija za presojokazalcevzvidikaugodnostiza sonaravnirazvoj. Osnovazapodanepozitivnealinegativne ocene je bilo odklanjanje od aritmetične sredine regij, kar je na drugi stopnji agregiranja omogočilo izračun povprečnih ocen za vsako od treh razvojnih področij in na najvišji stopnji na enak način tudi izračun tako imenovanega kazalca sonaravnega regionalnega razvoja. Posledično je bil vsaki skupini kazalcev (okoljskih, socialnih in ekonomskih) zagotovljen enak vpliv na višino sinteznega kazalca (Vintar, 2003). Uporabljeni metodološki koraki so omogočili ne le podrobno analizo razmer in trendov v posameznih regijah, ampak tudi obširno 
sintezno vrednotenje razvojnih razlik med regijami. Vendar pa je oblikovanje omenjenega alternativnega sinteznega kazalca odprlo tudi veliko novih vprašanj. Eno najpomembnejših se nanaša na način standardizacije, ki ne zagotavlja mednarodne primerljivosti, saj v svojem bistvu izhaja iz primerjav relativnega položaja regij glede na njihovo povprečje, kakor tudi ne medčasovne primerljivosti, ki je možna le znotraj posameznih kazalcev. Kot pri večini tovrstnih združevanj kazalcev je vedno prisotno tudi vprašanje pripisovanja ustrezne teže posameznim kazalcem, saj v praksi niti dva kazalca ne predstavljata vsebin z enakim vplivom na splošno blaginjo družbe. Vse omenjeno postavlja pred raziskovalce številne teoretične in metodološke izzive, ki jih bo mogoče premostiti šele dolgoročno. Vsekakor bo proučevanje moralo potekati v smeri združevanja čim bolj kakovostnih kazalcev v sintezne kazalce sonaravnega razvoja, ki bodo prinašali tudi bolj močna sporočila za širšo javnost in politiko ter bodo presegli trenutno utapljanje v poplavi raznolikih kazalcev s fragmentarnimi vsebinskimi sporočili.

Preglednica 1: Nabor kazalcev sonaravnega razvoja za slovenske statistične regije

Table 1: List of sustainable development indicators for statistical regions in Slovenia

\begin{tabular}{|c|c|c|}
\hline EKONOMSKI KAZALCI & SOCIALNI KAZALCI & OKOLJSKI KAZALCI \\
\hline 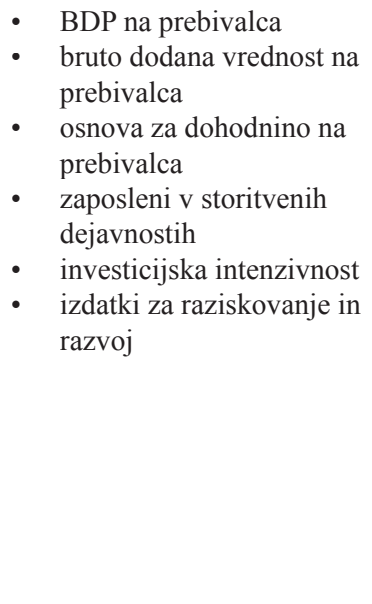 & $\begin{array}{ll}\text { - } & \text { gostota poselitve } \\
\text { - } & \text { rast prebivalstva } \\
\text { - žičakovana dolžina } \\
\text { - } \\
\text { povprečno število let } \\
\text { - } \quad \text { stopnja } \\
\text { - } & \text { neenakost plač } \\
\text { - } & \text { indeks staranja } \\
\text { - } & \text { dodiplomski študenti } \\
\text { - } & \text { brezposelni s I./II. stopnjo } \\
& \text { izobrazbe } \\
\text { - } & \text { stanovanjska površina na } \\
& \text { prebivalca } \\
\text { - } & \text { uporaba interneta } \\
\text { - } & \text { brezposelnost žensk }\end{array}$ & $\begin{array}{ll}\text { - } & \text { količina zbranih odpadkov } \\
\text { - } & \text { kakovost površinskih } \\
& \text { vodotokov } \\
\text { - } & \text { kakovost zraka }\left(\mathrm{SO}_{2}\right) \\
\text { - } & \text { delež zavarovanih območij } \\
\text { - } & \text { intenzivno obdelana } \\
& \text { kmetijska zemljišča } \\
\text { - } & \text { izdatki za varstvo okolja } \\
\text { - } & \text { gozdnate površine } \\
\text { - } & \text { delež pozidanih površin } \\
\text { - } & \text { stopnja motorizacije } \\
\text { - } & \text { železniški blagovni promet } \\
\text { - } & \text { živinorejojska gostota } \\
\text { - } & \text { ekološko obdelana kmetijska } \\
& \text { zemljišča } \\
\text { - čistilne naprave }\end{array}$ \\
\hline
\end{tabular}

Vir: Vintar, 2003

\section{SKLEP}

Sodobno družbo žene izrazita težnja po kvantitativnem zajemu vseh tistih pojavov in procesov, ki so v ospredju njenega zanimanja. Sprejetje trajnostne paradigme, ki je teoretično sicer še v marsičem nedorečena, je zato spodbudilo številne iniciative opredeljevanja kazalcev sonaravnega razvoja. Večina pobud se je odvijala v smeri opredeljevanja obsežnih naborov z več desetinami kazalcev, ki pa jih ne znamo pripeljati na skupni imenovalec in tako iz njih pridobiti enovito informacijo. Poleg tega spremljajo uporabo kazalcev tudi številne vsebinske, 
metodološke, institucionalne in tehnične omejitve, zaradi česar ne igrajo želene vloge pri usmerjanju človekovih dejavnosti na okolju in človeški družbi bolj prijazno razvojno pot.

Kljub vsem naštetim teoretičnim in metodološkim zadregam ne velja opustiti upanja, da bo z razvojem metodologije in izboljšanjem zbiranja ter kakovosti podatkov mogoče priti do optimalnega modela oziroma sistema kazalcev sonaravnega razvoja. Povsem mogoče pa je tudi, da se bo sčasoma merjenje napredka preusmerilo drugam in bodo dosedanja prizadevanja predstavljala zgolj slepo ulico. Preobrat utegne pomeniti uporaba malega števila sinteznih kazalcev, ki bi vključevali le en ali dva kazalca za ekonomsko, socialno in okoljsko področje. V to smer se že sedaj odvijajo prizadevanja po nadgradnji določenih sinteznih kazalcev, kot so »zelenitev« sistema nacionalnih računov, soočanje indeksa človekovega razvoja ter ekološkega odtisa in podobno. Ne glede na razplet je najbolj pomembno, da bodo pridobljene informacije tudi dejansko prispevale $\mathrm{k}$ iskanju možnosti socialnoekonomskega razvoja znotraj okoljskih omejitev, kar je temeljna zahteva dolgoročnega trajnostnega razvoja in kakovostnega preživetja prihodnjih generacij.

\section{Viri in literatura}

Agenda 21. 1992. Programme of Action for Sustainable Development, Rio Declaration on Environment and Development. The United Nations Conference on Environment and Development. Rio de Janeiro.

Assessing Sustainable Development: Principles in Practice. 1997. Hardi, P., Zdan, T. J.(ed.). Winnipeg, International Institute for Sustainable Development.

A Sustainable Europe for a Better World: A European Union Strategy for Sustainable Development. 2001. Brussels, Commission of the European Communities.

Birkmann, J., 1999. Indikatoren für eine nachhaltige Entwicklung. Raumforschung und Raumordnung, 57, 2-3, str. 120-131.

Born, M., 1999. InternationaleBeispielekommunaler Indikatorensystemeals Orientierungshilfe für deutsche Kommunen. V: Indikatorensysteme für eine nachhaltige Entwicklung in Kommunen. Berlin, Deutsches Institut für Urbanistik, str. 61-73.

Bossel, H., 1999. Indicators for Sustainable Development: Theory, Method, Applications.

A Report to Balaton Group. Winnipeg, The International Institute for Sustainable Development.

Compendium: a global directory to indicator initiatives - International Institute for Sustainable Development. URL: http://www.iisd.org/measure/compendium/searchinitiatives.aspx (citirano 1.6.2006)

Environmental Indicators. Typology and overview. 1999. Copenhagen, European Environment Agency.

Environmental signals 2002. 2002. Copenhagen, European Environment Agency.

Final report of the Sustainable Development Indicators Task-Force. 2005. URL: http:// epp.eurostat.ec.europa.eu/portal/page?_pageid=1998,47433161,1998_47437059\&_ $\mathrm{dad}=$ portal\&_schema=PORTAL (citirano 20.5.2005). 
Franke, W., 1999. Indikatoren zur Messung einer nachhaltigen Entwicklung auf Landesebene.

V: Indikatorensysteme für eine nachhaltige Entwicklung in Kommunen. Berlin, Deutsches Institut für Urbanistik, str. 29-38.

Frings, E., 1999. Indikatoren und Kennzahlen in der Umweltberichterstattung - Aufgaben und Anforderungen. V: Indikatorensysteme für eine nachhaltige Entwicklung in Kommunen. Berlin, Deutsches Institut für Urbanistik, str. 49-60.

Gulič, A., Praper, S., 2000. Indicators as Tools for Sustainable Local Development. IB Revija, 34, 3-4, str. 82-87.

Hardi, P., Barg, S., in drugi, 1997. Measuring Sustainable Development: Review of Current Practice. Occasional Paper Number 17, Ottawa, Industry Canada.

Hönerbach, F., 1999. Nachhaltigkeitsindikatorensysteme in Deutschland und im internationalen Bereich. V: Indikatorensysteme für eine nachhaltige Entwicklung in Kommunen. Berlin, Deutsches Institut für Urbanistik, str. 11-27.

Indicators of Sustainable Development. A pilot study following the methodology of the United Nations Commission on Sustainable Development. 1997. Luxembourg, Office for Official Publications of the European Communities.

Indicators of Sustainable Development: Guidelines and Methodologies. 2001. New York, United Nations Commission on Sustainable Development.

Indikatorji trajnostnega razvoja za Mestno občino Ljubljana. Zaključno poročilo prve faze. 1999. Ljubljana, Urbanistični inštitut Republike Slovenije.

Kistenmacher, H., Mangels, K., 2000. Regionalmanagement als Motor für eine nachhaltige Raumentwicklung? Raumforschung und Raumordnung, 58, 2-3, str. 89-102.

Koitka, H., Kreft, H., 2000. Gemeinsam Indikatoren entwickeln! Ein neuer Baustein für erfolgreiche regionale Agenda-21-Prozesse. Raumforschung und Raumordnung, 58, 6, str. 488-498.

Meadows, D., 1998. Indicators and Information Systems for Sustainable Development. A Report to the Balaton Group. Vermont, The Sustainability Institute.

Measuring progress towards a more sustainable Europe. 2005. Luxembourg, Office for Official Publications of the European Communities.

Morse, S., 2004. Indices and Indicators in Development. An Unhealthy Obsession with Numbers. London, Earthscan.

Petek, F., 2001. Vrednotenje rabe zemljišč v slovenskih pokrajinah z vidika kazalcev sonaravnega razvoja: magistrsko delo. Ljubljana, Filozofska fakulteta, Oddelek za geografijo.

Pinter, L., Hardi, P., Bartelmus, P., 2005. Sustainable Development Indicators: Propolsals for the Way Forward. New York, International Institute for Sustainable Development, UN Division for Sustainable Development.

Plan of implementation. World Summit on Sustainable development (advance unedited text - 4 September 2002). 2002. URL: http//www.iisd.ca/linkages/2002/wssd/PlanFinal.pdf (citirano 14.9.2002).

Plut, D., 2002. Teoretični in terminološki vidiki koncepta trajnostnosti/sonaravnosti. Geografski vestnik, 74, 1, str. 73-86. 
Plut, D., 2005. Teoretična in vsebinska zasnova trajnostno sonaravnega napredka. V: Geografski pogledi na regionalni razvoj. Ljubljana, Filozofska fakulteta, Oddelek za geografijo (Dela, 23, str. 59-113).

Poročilo o razvoju. 2002. Murn, A., Kmet, R. (ur.). Ljubljana, Urad RS za makroekonomske analize in razvoj.

Radej, B., 1999. Razvoj indikatorjev za vrednotenje okoljske kakovosti gospodarske rasti. Delovni zvezek, 7, 10, Urad RS za makroekonomske analize in razvoj.

Seljak, J., 2000. Merjenje uravnoteženega razvoja: doktorska disertacija. Ljubljana, Ekonomska fakulteta.

Seljak, J., 2001. Kazalec uravnoteženega razvoja. Ljubljana, Urad za makroekonomske analize in razvoj.

Vester, F., 1991. Kriza prenaseljenih območij. O razvijanju ekosistemskega mišljenja. Ljubljana, DZS.

Vintar, K., 2003. Okoljevarstveni vidiki sonaravnega regionalnega razvoja Slovenije: magistrsko delo. Ljubljana, Filozofska fakulteta, Oddelek za geografijo.

Vrišer, I., 1992. Uvod v geografijo. Ljubljana, Filozofska fakulteta, Oddelek za geografijo.

\section{ADVANTAGES AND LIMITATIONS OF SUSTAINABLE DEVELOPMENT INDICATORS}

\section{Summary}

Modern society is driven by an explicit desire to quantify all the phenomena and processes that are of its interest. Achieving sustainable development has become one of the main global goals, although the new paradigm still raises a lot of theoretical questions. Consequently, we have no exact definition of such a development nor do we know what and how to measure, how to interpret quantitative information and judge its significance. However, monitoring and measuring the progress is of vital importance in order to make the concept of sustainable development operational. To this end, the majority of sustainable development measurement approaches is based on sets of so called sustainable development indicators.

Indicators of sustainable development serve as tools for translating the concept into practical terms, defining concrete development goals and measures, and as an orientation for making political decisions and evaluating the progress of achieving the goals. Last but not least, they allow us to make detailed comparisons between and within selected spatial levels. Each set of selected indicators should be based on a conceptual model that helps to organize the individual issues, which should be measured by the indicators. Among different models (for example, pressure-state-response models, multiple capital models, linked humanecosystem well-being models and theme-based models) only a few gained international acceptance. Nowadays, the most widely used is the theme model (also known as the issue- or theme-based framework or the three component model) with three main thematic categories (economic, social, environmental). In particular, the paper analyses three indicator sets, that were developed by the United Nations and the European Union to measure progress at the 
national level and by the author to measure progress at the regional level in Slovenia. All three theme-based sets of indicators served as an example to empirically evaluate the advantages and limitations of the indicator use.

The choice of indicators for certain themes and sub-themes is certainly the most demanding and responsible step of the whole research. The ideal indicators should be relevant to decision-making, understandable with simple and traceable way of calculation, not over- or under-aggregated, clear about desirable value (possibly with clear reference value), measurable at reasonable cost and without long delays, sensitive to changes in time and space, internationally comparable, enabling comparisons between and within selected spatial levels etc. Moreover, the sets of indicators should be formed in a balanced way in order to attribute an equal weight to economic, social and environmental aspects of development. As there are no ideal indicators that would perfectly reflect the reality and meet all the criteria, there are also no ideal sets of indicators. All indicators are imperfect and their choice is always at least partially subjective, based upon the values in a certain society. The most important limitation of indicator use is the lack of data, especially on social and environmental issues, making many proposed indicators unfeasible. There is not only a great demand for new data but also for new approaches to existing data and their integration. Sometimes we are forced to use the "best available" data and indicators instead of the "best needed". Many other limitations refer also to methodological, institutional and technical challenges, which prevent indicators of sustainable development from being more influential in mainstream politics and decision making.

Developing and improving sustainable development indicators has already come a long way, but we still miss the ways to aggregate the selected indicators properly. The majority of current research work focuses on the analysis of individual indicators, examining past and predicting future trends, and on the search for linkages between different social, economic and environmental variables. In order to prevent the users from drowning in the flood of statistical data, aggregation of good quality indicators is necessary, providing useful and politically strong messages.

In the long run, the development of an optimum model and a set of sustainable development indicators can be expected. However, it is also possible that the progress measuring will change the direction and that current sets of numerous indicators will present only a dead-end street along the way. Regardless of the methodology used, the collected information have to really contribute to the search for the possibilities of socio-economic development within the existing environmental limits, which is the fundamental requirement of sustainable development. 